\title{
Influence of Service Quality of Agricultural Products E-commerce Platform on Customer Loyalty - The Mediating Role of Customer Engagement
}

\author{
Ning $\mathrm{Hu}^{1}, \mathrm{Xi} \mathrm{Chen}^{2 *}$ and Ning Zhang \\ 1,2*3B Business School, Shandong Jianzhu University, Jinan 250101, China \\ ${ }^{2 *}$ chenxi0801@naver.com
}

\begin{abstract}
With the popularity of computer networks and advances in information technology, online shopping has become a major way. The net purchase of agricultural products is becoming a new growth trend. The speed of China's agricultural development of the electronic business platform is very fast, from the customer's perspective on how to improve the experience and level of service of the electronic business platform to achieve engagement and loyalty, become the focus of attention of scholars. Existing research results show that electronic service quality directly affects customer loyalty. Based on existing theory, this paper focuses on the influence of electronic service quality and customer loyalty. At the same time, customer engagement is also considered and together established a new model. The empirical test is conducted by using the data processing software SPSS 26.0 and AMOS 24.0 to analyze the 433 questionnaires gained from random interviews and online fill out. AMOS (version 24.0) was used to estimate both the measurement and structural models. The test shows that the electronic service quality (process quality, outcome quality, recovery quality) has a prominent positive effect on customer engagement and so does the engagement to loyalty. Service recovery quality can not only directly affect customer loyalty, but also indirectly affect customer loyalty through customer engagement, while service process quality and service result quality affect customer loyalty through customer engagement. On one hand, these theories rich the traditional customer relation model by introducing customer engagement as an intervening variable, which is more correspondent to the current online shopping environment. On the other hand, this paper is conducted with the premier of electronic agriculture product business background, the result can supply some practical management advice for developing customer loyalty in this field.
\end{abstract}

Keywords: E-business platform of agricultural, E-service quality, Customer engagement, Customer loyalty

\section{Introduction}

With the continuous progress and popularization of computer network technology and the rapid development of online shopping, online shopping has become the main way of people's shopping. At the same time, there are more and more choices for online shopping. Among them, people's online shopping of agricultural products has gradually become a new growth trend, and agricultural products have become a new product for consumers to buy online. With the concept of "Internet plus agriculture" put forward, the prospects of agricultural products will

Article history:

Received (January 8, 2021), Review Result (February 12, 2021), Accepted (March 18, 2021) 
also be broader. It will give birth to new formats of rural electricity business and become a new engine and new power for China's economic transformation.

Reviewing the existing research on the e-commerce platform of agricultural products, up to now, most of them are based on the qualitative analysis of the development model of ecommerce platform of agricultural products [1], while the quantitative empirical analysis is less. Among the few empirical studies based on consumer behavior, Fei took agricultural products as an example to analyze the impact of service quality of agricultural products ecommerce platform on consumers' willingness to buy agricultural products online and divided service quality into three dimensions: service environment quality, service process quality, and service result quality. Wang used the method of network survey to discuss consumption [2]. Li et al. found in the research on the development of fresh organic e-commerce platforms in China that user loyalty is not easy to maintain [3]. Therefore, in the e-commerce environment, in the face of repeated purchases of agricultural products, it is still very important to study the customer loyalty of agricultural products e-commerce platforms.

A significant literature study states that service quality will positively affect consumers' repeat purchases and loyalty. Besides customer satisfaction, we are also looking for other mediating variables that can lead to customer loyalty, such as trust [4], perceived value [5], etc. In recent years, due to the popularity and development of e-commerce, scholars began to focus on the role of participation and interaction [6] in the long-term relationship between customers and enterprises. In this context, Customer engagement has been proposed. Now, Customer engagement is introduced. How can customers achieve fit when they accept the service of agricultural products e-commerce platform, to trigger customer loyalty, repeat purchase, wordof-mouth recommendation, and other behaviors?

Based on the existing literature review, this paper starts from the perspective of service quality of the E-Business platform of agriculture and explores whether the service quality of the E-Business platform of agriculture will affect consumers' customer loyalty through empirical research. Based on the background of the Internet, this paper introduces the variable of Customer engagement into the existing research, breaks the original research path, and reveals the influence path of service quality and customer engagement of the E-Business platform of agricultural on customer loyalty. Nowadays, under the background of fierce competition between e-commerce of agricultural products, the e-commerce platform of agricultural products can provide theoretical reference for cultivating Customer engagement and enhancing real customer loyalty, and finally achieving the increase of benefits.

The second part of this paper is a literature review and hypotheses development. This part summarizes the concept and dimension definition of service quality, customer engagement, and customer employability. Based on the literature review, this paper puts forward the hypothesis of this study and constructs the research model. This paper will examine the impact of service quality of e-commerce platforms for agricultural products on customer loyalty. Service quality has a positive impact on customer engagement. Customer engagement has a positive impact on customer loyalty. After presenting the methodology and data analysis, we discuss the findings and implications in the last section.

\section{Literature review and hypothesis development}

\subsection{Service quality}

The academic research on service quality began in the 1970s and 1980s. The earliest definition of service quality is that it is the same as the result of previous standards and services 
[7]. Sasser et al. thought that we should not only consider the result of service, but also the process of service delivery [8]. Then, Gronroos thinks that service quality is a kind of perception of service, the service quality perceived by customers is the key to the success of enterprises, and the service quality is subjectively evaluated by customers themselves [9]. At this time, the concept of perceived service quality appeared for the first time in academic circles. Gronroos combined with the theory of cognitive psychology defined the concept of customer perceived service quality as a result of the comparison between the initial level of customer expectation for service quality and the level of customer perceived service quality, in reality, it emphasizes the gap between the service and expectation that customers feel in the process of enjoying the service. In the first mock exam, he also proposed a model of perceived service quality, which has been recognized by the academic circles and has become the basis for future scholars. With the deepening of the research, Parasurama et al. developed and improved the service quality model, thinking that service quality is the gap between the service level perceived by customers and the service quality expected before [10]. In other words, the quality of service is equal to the original expected service minus the real cognitive service. Customer-perceived service quality is the subjective evaluation of service, and it is the result of the comparison between customer's subjective expectations and actual perceived service level, which shows the quality of service. On this basis, domestic scholars give a similar definition. The definition should be given from the perspective of the service recipient and service provider. In the aspect of the service recipient, it means that the actual service received by customers has reached or exceeded the original expectation; in the aspect of the service provider, it means that the service level has reached the previous expectation [11].

The quality of service in this paper refers to the online quality of service, also known as electronic quality of service, which is developed and evolved from the traditional quality of service. Nowadays, with the popularization of Internet information technology, the development trend of electronic network service is further accelerated. Therefore, under the background of the network, more and more scholars begin to pay attention to the research of online service quality. Zeithaml et al. defined e-service quality (e-SQ) for the first time. E-SQ is regarded as the degree of service that online enterprises provide to ensure that customers can more easily and efficiently select, purchase, and deliver products from the website [12]. Therefore, e-service quality is a comprehensive measurement of online shopping services in all aspects. The definition is based on the whole online shopping process with the consumer online shopping website as the interactive object, including the website service quality perceived by the consumer when using the website for shopping and the service result quality of the later website. At this time, some scholars try to define e-service quality from other aspects. Gummerus et al. think that consumers can use Internet information technology to interact with a variety of online products and service providers [13]. This interaction includes the evaluation of the process and result. Chen proposed that the quality of electronic service is the subjective comparison and cognition between the psychological expectation and the information you need when you use a website to find and search the information you need [14]. Li et al. believe that in the context of the Internet e-commerce environment, customer-perceived service quality is e-service quality [15]. Bauer et al. put forward a similar point of view, they believe that the concept of e-service quality is only in the online purchase with internet information technology as the interactive object [16]. Customers are the key players in perceiving services with a variety of attributes related to their knowledge, experience, and desires. These expectations direct their purchase intention, emotional response, buying decisions, and repurchase behavior. Service quality and customer satisfaction are viewed together in business for their success [17]. 


\subsection{Customer engagement}

Customer engagement is a state of mind of being emotionally invested with the focal object (brand or medium), which leads to customers' frequent interactions with the focal object [18]. Since Kaln put forward the concept of engagement in 1900, the academic community began to pay more attention to it. Many scholars have carried out mutual research in different fields. In recent years, some scholars in the marketing domain have shown interest in engagement and have put forward the concept of customer engagement [35]. IIIc summarized the previous research on engagement and discussed employee engagement in organizational behavior, Scholars in educational psychology discuss student engagement, and social psychology studies social engagement. In recent years, engagement has been introduced into the field of marketing. The traditional view is that customers are exogenous to the enterprise [19], and they are passive recipients and destroyers of value. However, with the rapid development of the social economy, market competition is intensified, and the emergence of networks and other new social media leads to the change of customers' perspectives. They think that customers can create value for enterprises [20]. Some even think that enterprises only play the role of partners, and customers are the real value creators [21]. With the rapid development of new media and the transformation of marketing ideas (the strengthening of service-oriented logic and the prevalence of relationship marketing paradigm), the concept of customer engagement (CE) is proposed. In this context, enterprises should further improve the management of customer relationships, achieve customer engagement, improve enterprise efficiency, and obtain a competitive advantage [22].

As word-of-mouth is a manifestation of customer engagement, we can define social mediadriven customer engagement as the "manifestations from customers toward a firm or a brand beyond purchase" [23], motivated by social media affordances. Social media foster online customer manifestations toward a firm/brand through social affordances, fulfilling users' needs [24]. Some studies have shown that customer engagement can improve users' continuous use [25], strengthen emotional commitment [26], promote customers' trust in enterprises and customer satisfaction [27], improve enterprise reputation, form customer loyalty [28], and then improve enterprise performance [29]. Also, Han and Yuan (2013) investigated the mechanism of customer engagement influencing customer behavior intention from the perspective of brand equity. For the problem of customer engagement, scholars still focus on the definition and dimension or use qualitative research methods to explore the mechanism of customer engagement. Although there is no unified concept of customer engagement, scholars all agree that customer engagement is a psychological state between customers and enterprises in the process of repeated and co-creating value. Therefore, on the one hand, applying customer engagement to the experience of agricultural products e-commerce platforms will also have a certain impact on customer engagement, that is, customer perceived product quality, service quality, and service quality will have an impact on customer engagement. On the other hand, the factors influencing customer engagement include perceived quality, customer satisfaction, customer involvement, etc.

\subsection{Customer loyalty}

At present, there are many researches on the concept of customer loyalty. customer loyalty, including the fact that having loyal customers reduces service costs, their willingness to pay more for products or services, and free word-of-mouth marketing [30]. From the perspective of behavior, Anderson and Sullivan believe that customer loyalty is a kind of behavior of customers repurchase [31]. Gremler and Brown take the service industry as the research object 
and define it as the frequency of customers' repeated purchases from a specific enterprise with a positive attitude, and when there is a demand for repurchase, they will continue to choose the original enterprise [32]. Han and Wei defined customer loyalty as the long-term behavior of customers choosing the brand or service due to the influence of product price, quality, and service [33]. From the perspective of single behavior, the definition of customer loyalty has been questioned by scholars. They put forward that customers' repeat purchase behavior may be because consumers have too few choices and not enough substitutes; or it is a regular habit behavior, which is not true loyalty. Then, from the perspective of attitude, Zeithaml pointed out that customer loyalty is a willingness to maintain a long-term relationship between customers and enterprises [12]. Lu and Song pointed out that customer loyalty is the degree of customer attachment to enterprise products and services [34]. Subsequently, Shankar et al. found that loyal consumers have a firm willingness to consume and are not easily convinced by others, and they are more willing to recommend products and services to others [35]. At present, it is easy for academic circles to consider the combination of attitude and behavior to explain customer loyalty. Among them, the main representative viewpoints are: Dick and Basu pointed out that customer loyalty is determined by consumers' positive purchase attitude and continuous purchase behavior [36]. Oliver made a pioneering contribution to the definition of customer loyalty on this basis [37]. He believed that customer loyalty is the strong will and commitment of consumers in the process of long-term purchase and selection of their favorite products and services, as well as the actual repeated purchase behavior. No matter the impact of the situation, it will not produce the behavior of conversion. Ma and Zhang pointed out that customer loyalty refers to the dependence of customers when they purchase the products and services of an enterprise [38]. They have a preference attitude and will make repeated purchases, and will actively promote and recommend for the enterprise. In other words, customer loyalty is a combination of attitude and behavior. Loyalty is not only reflected in the behavior loyalty of repeated purchase but also includes the positive attitude loyalty to a certain product and brand [39].

Based on the research situation of an e-commerce platform for agricultural products, this paper takes customer loyalty as a whole and considers it from two aspects of attitude and behavior loyalty. Customer loyalty is a kind of preference and dependence on agricultural products when consumers purchase agricultural products on the e-commerce platform for agricultural products.

\subsection{E-commerce platform service quality and customer engagement}

With the change of marketing concept, scholars begin to think that customer engagement can not only create profits for enterprises but also provide value activities for customers [40]. According to the theory of customer value, customer value refers to the value increase perceived by customers when they experience the products or services provided by enterprises, and then emotional attachment will be formed between customers and value providers [41]. At present, there is no accepted definition of customer engagement, Previous studies have generally believed that customer engagement is a psychological state formed in the process of repeating and creating value for enterprises [42]. When customers shop on the e-commerce platform of agricultural products, they feel the quality of the service process and service result in turn. If the e-commerce platform of agricultural products makes mistakes in service, they will experience quality-of-service recovery. In these three stages, when customers feel more service, they will establish an emotional bond with the e-commerce platform. Therefore, if customers feel that shopping on the website platform has a good experience, it will lead to 
customer engagement. In other words, the level of service quality perceived by consumers at various stages of e-commerce platform shopping may lead to customer engagement. Reitz proposed an online customer engagement model based on his research and analyzed the experience of Facebook users. The results also showed that customer-perceived information service quality has a positive correlation with customer engagement [43]. Claussen et al. found that the quality of their software is customer engagement through the empirical study of Facebook users [44]. The meaning of customer engagement is close to the concepts of customer involvement and customer participation [45], and the research on the relationship between service quality and customer involvement and customer participation also supports the above reasoning. Therefore, this paper puts forward the following hypotheses.

H1: The service quality of agricultural products e-commerce platform has a positive impact on customer engagement.

H1a: The service process quality has a positive impact on customer engagement.

H1b: The service outcome quality has a positive impact on customer engagement.

H1c: The service recovery quality has a positive impact on customer engagement.

\subsection{E-commerce platform customer engagement and customer loyalty}

Research shows that customer engagement can improve users' continuous use [46], and users' continuous use is the embodiment of customer loyalty to some extent. According to the theory of Brodie et al., customer engagement may be the antecedent variable of customer loyalty. When the corresponding customers believe that the enterprise is reliable and honest, there will be trust between the two sides. The higher the degree of fit, the higher the customer's attachment to the enterprise, the higher the emotional commitment between them, and the more can lead to customer loyalty. At the same time, the research of Han et al. shows that customer engagement can form customer loyalty and has a significant positive impact on customer loyalty. Samala et al. empirically confirmed that customer engagement enhances tourist satisfaction, trust, and loyalty of certain tourism brands [47].

Therefore, this paper puts forward the following hypotheses.

H2: Customer engagement has a positive impact on customer loyalty.

\subsection{E-commerce platform service quality and customer loyalty}

In 1986, Davis combined Ajzen's TPB and Hshbein's TRA to put forward Tam and formed Tam. This model mainly explains perceived usefulness and perceived ease of use to predict and analyze users' behavior. Then, in the aspect of the model expansion, Celik et al. added perceived information quality, system quality, and service quality to the classic TAM model when they studied online shopping, explaining the problem of user continuous use [48]. If the relationship between consumers and the e-commerce platform of agricultural products is divided according to the time order of shopping, it can be roughly divided into pre-purchase, mid-purchase, and post-purchase. Tam theory can well explain the perceived service quality of consumers before, mid purchase, and post-purchase of the e-commerce platform of agricultural products.

According to the existing customer relationship theory, providing high-quality service can improve and maintain customer loyalty. Important literature verified the direct relationship between service quality and customer loyalty in the network environment [49][50]. Meanwhile, Wolfinbarger and illy found that customer loyalty is the outcome variable of e-sq. Subsequently, some scholars have also done some research on the impact of different dimensions of e-service 
quality on customer loyalty. Marimon et al. tested the positive impact of e-service quality responsiveness on customer loyalty through empirical research. Qi et al. did not use the concept of e-service quality, but also tested that website convenience has a significant positive impact on customer loyalty, which has the same factor components as e-service quality. Also, scholars (2009) verified that website service quality (service process quality, service result quality, and service recovery quality) has a positive impact on customer loyalty under the background of online shopping. Among them, the quality-of-service results also directly affect customer loyalty through the intermediary variable of customer trust. Then, Zhang et al. demonstrated that service process quality and service recovery quality have a significant direct impact on customer loyalty from three aspects of service process quality, service recovery quality, and service result quality, taking online shopping in China as the research background.

To sum up, the theoretical basis and existing literature show that there is a direct effect between service quality and customer loyalty. Therefore, this paper puts forward the following hypotheses.

H3: The service quality of agricultural products e-commerce platform has a positive impact on customer loyalty.

H3a: The positive effect of service process quality on customer loyalty.

$\mathrm{H} 3 \mathrm{~b}$ : The positive effect of service outcome quality on customer loyalty.

$\mathrm{H} 3 \mathrm{c}$ : The positive effect of service recovery quality on customer loyalty.

\section{Materials and methods}

\subsection{Theoretical model}

This paper will examine the impact of service quality of e-commerce platforms for agricultural products on customer loyalty. Service quality (process quality, outcome quality, recovery quality) has a positive impact on customer engagement. Customer engagement has a positive impact on customer loyalty. This part summarizes the hypotheses mentioned above and draws the research model as shown in [Figure 1].

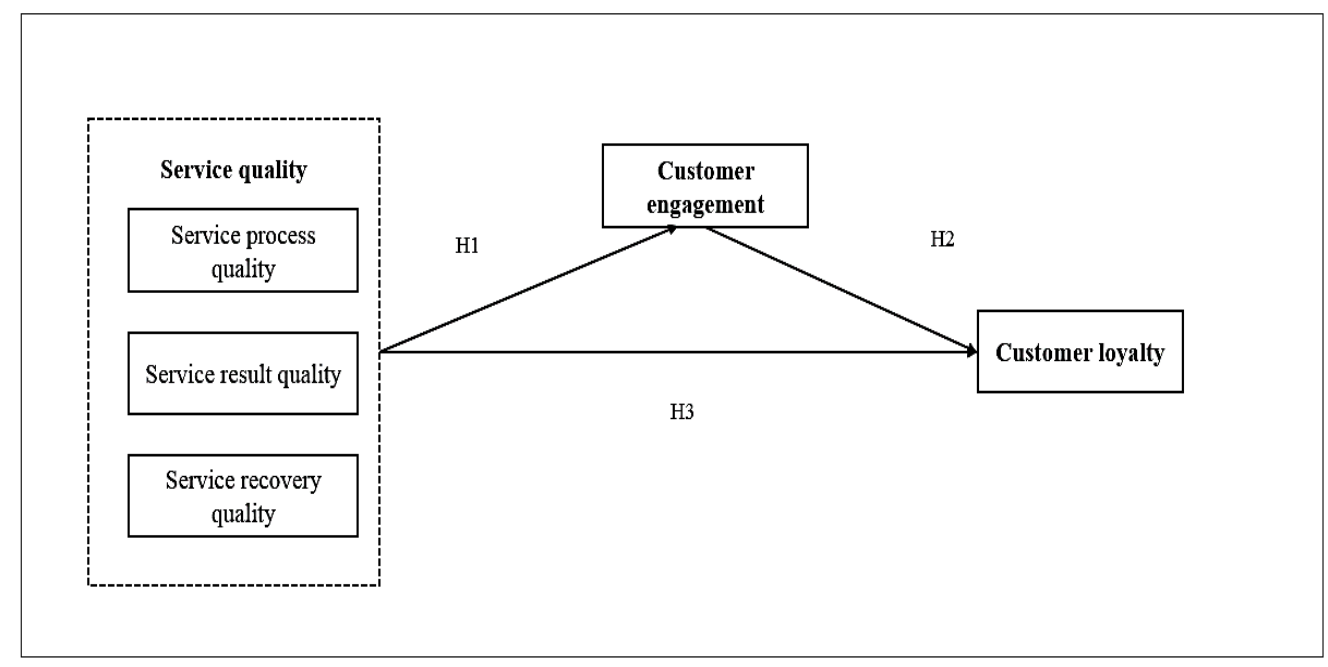

Figure 1. The research framework 


\subsection{Measurement scaling for constructs and items}

Sociodemographic measures include marital gender, age, average monthly income, and occupation. Sex was measured dichotomously. The age range was measured using an ordinal scale. The occupation was also measured using an ordinal scale, and agricultural products usually purchased were measured in the local currency and subsequently converted into U.S. dollars.

The questionnaire in this paper uses the 7-point Likert scale. For each measurement item, 17 points represent from "totally disagree" to "completely agree". The measurement items of each variable are based on the measurement items that have been verified to be trustworthy and appropriate in the previous study and are modified in combination with the situation of this study. The content of measurement items is shown in [Table 1].

Table 1. Variable scale

\begin{tabular}{|c|c|c|}
\hline Part & Question item & Researcher \\
\hline \multirow{6}{*}{$\begin{array}{l}\text { Service process } \\
\text { quality ( } 6 \text { items) }\end{array}$} & $\begin{array}{l}\text { The web design of the website is very convenient for you to } \\
\text { find the agricultural products and information you need to buy. }\end{array}$ & \multirow{16}{*}{$\begin{array}{c}\text { Zeithaml et al } \\
\text { (2002), } \\
\text { Parasuraman et al } \\
\text { (2005), } \\
\text { Collier \& Bienstock } \\
\text { (2006) }\end{array}$} \\
\hline & $\begin{array}{l}\text { The web design of the website can give people a clean and } \\
\text { professional feeling. }\end{array}$ & \\
\hline & $\begin{array}{l}\text { The website search engine function is strong, easy to find want } \\
\text { to buy agricultural products. }\end{array}$ & \\
\hline & The website will not abuse your personal information. & \\
\hline & $\begin{array}{l}\text { The website can provide sufficient and timely updated } \\
\text { information on agricultural products. }\end{array}$ & \\
\hline & The website processes transactions quickly. & \\
\hline \multirow{6}{*}{$\begin{array}{c}\text { Service result } \\
\text { quality (6 items) }\end{array}$} & $\begin{array}{l}\text { The website can deliver the purchased agricultural products at } \\
\text { the time you require them. }\end{array}$ & \\
\hline & $\begin{array}{l}\text { The agricultural products delivered by this website are } \\
\text { consistent with your expectation. }\end{array}$ & \\
\hline & $\begin{array}{l}\text { The agricultural products delivered by the website are } \\
\text { consistent with their advertising. }\end{array}$ & \\
\hline & $\begin{array}{l}\text { The agricultural products delivered by the website are in good } \\
\text { condition. }\end{array}$ & \\
\hline & The website business can fulfill the promise. & \\
\hline & $\begin{array}{l}\text { The merchants of the website can accurately deliver the } \\
\text { purchased agricultural products. }\end{array}$ & \\
\hline \multirow{4}{*}{$\begin{array}{l}\text { Service recovery } \\
\text { quality } \\
\text { (4 items) }\end{array}$} & $\begin{array}{l}\text { When there is a problem with the transaction, the website } \\
\text { service staff can tell you how to do it. }\end{array}$ & \\
\hline & $\begin{array}{c}\text { The service staff of the website can solve your problems } \\
\text { friendly and quickly. }\end{array}$ & \\
\hline & $\begin{array}{l}\text { When the transaction problems, the site will take the initiative } \\
\text { to apologize to you. }\end{array}$ & \\
\hline & $\begin{array}{l}\text { The website will compensate you for the loss due to the quality } \\
\text { problems of its agricultural products. }\end{array}$ & \\
\hline \multirow{3}{*}{$\begin{array}{c}\text { Customer } \\
\text { engagement } \\
\text { (3 items) }\end{array}$} & $\begin{array}{l}\text { Spent a lot of time on the agricultural products e-commerce } \\
\text { platform. }\end{array}$ & \multirow{3}{*}{$\begin{array}{l}\text { Vivek } \\
(2009)\end{array}$} \\
\hline & $\begin{array}{l}\text { Anything related to this business station will attract your } \\
\text { attention. }\end{array}$ & \\
\hline & $\begin{array}{l}\text { You like to share the experience of using the agricultural } \\
\text { products e-commerce platform with your friends. }\end{array}$ & \\
\hline
\end{tabular}




\begin{tabular}{|c|c|c|}
\hline \multirow{6}{*}{$\begin{array}{l}\text { Customer loyalty } \\
\text { (6 items) }\end{array}$} & $\begin{array}{l}\text { When you need to buy agricultural products online, this } \\
\text { platform is your first choice. }\end{array}$ & \multirow{6}{*}{$\begin{array}{c}\text { Kassim \& } \\
\text { Abdullah } \\
(2010)\end{array}$} \\
\hline & $\begin{array}{l}\text { Even if other e-commerce platforms for agricultural products } \\
\text { have lower prices Nong agricultural products, they will not } \\
\text { easily turn to other e-commerce platforms for agricultural } \\
\text { products. }\end{array}$ & \\
\hline & $\begin{array}{l}\text { You will continue to buy agricultural products on the } \\
\text { agricultural products e-commerce platform. }\end{array}$ & \\
\hline & $\begin{array}{l}\text { Compared with the e-commerce of agricultural products, you } \\
\text { consume more on this platform. }\end{array}$ & \\
\hline & $\begin{array}{l}\text { You prefer this platform to the e-commerce of agricultural } \\
\text { products. }\end{array}$ & \\
\hline & $\begin{array}{l}\text { You will recommend this e-commerce platform for agricultural } \\
\text { products to others. }\end{array}$ & \\
\hline
\end{tabular}

\section{Data analysis and results}

\subsection{Analysis of sample characteristics}

This survey was carried out through an online crowdsourcing platform in China, which provides functions equivalent to Amazon Mechanical Turk. The online survey platform used in this paper is the most representative in China. Therefore, the representativeness of the sample for the survey method. Before the formal questionnaire was issued, 20 people (10 men and 10 women) were pretested in a small range. According to the results of the pretest, some sentences in the questionnaire were properly adjusted to form a formal questionnaire.

The formal questionnaire was issued from November to December 2020. In this study, a non-random sampling survey was adopted. Through a questionnaire survey of 470 customers who purchase agricultural products through the e-commerce platform, 37 invalid questionnaires, which are the questionnaires with inaccurate answers, inconsistent answers, and careless content filling, were eliminated, and 433 valid questionnaires were collected. The sampling efficiency was $92.1 \%$.

Among the effective data samples collected, $44.8 \%$ were men and $55.2 \%$ were women. According to the age distribution, $3.2 \%$ were under 20 years old, $50.8 \%$ were $20-39$ years old, $43.2 \%$ were $40-59$ years old, and $2.8 \%$ were over 60 years old. According to the occupational distribution, $9.9 \%$ were civil servants and institutions, $17.1 \%$ were enterprise employees, $3.5 \%$ were self-employed, $2.1 \%$ were students, $26.6 \%$ were retired, $40.9 \%$ were unemployed or others. According to the distribution of educational background, $20.1 \%$ of them have a high school education background, $23.3 \%$ have a junior college education background, $36.0 \%$ have an undergraduate education background, and $20.6 \%$ have a graduate education background or above. In terms of economic level, $53.3 \%$ are below the middle level, $41.8 \%$ are above the middle level, and $4.8 \%$ are above the middle level. In terms of the agricultural products usually purchased, fruit for $25.9 \%$, vegetable for $28.9 \%$, meat and egg for $21.5 \%$, aquatic product for $15.9 \%$, and others for $7.8 \%$. The statistics are shown in [Table 2]. 
Table 2. Demographics of the survey respondents $(\mathrm{N}=433)$

\begin{tabular}{|c|c|c|c|}
\hline Item & Characteristic & Number of Samples & Percentage \\
\hline \multirow{2}{*}{ Gender } & Male & 194 & $44.8 \%$ \\
& Female & 239 & $55.2 \%$ \\
\hline \multirow{4}{*}{ Age } & 20 or younger & 14 & $3.2 \%$ \\
& $21-40$ & 220 & $50.8 \%$ \\
& $41-60$ & 187 & $43.2 \%$ \\
& 60 or older & 12 & $2.8 \%$ \\
\hline \multirow{4}{*}{ Occupation } & Institution and civil servant & 43 & $9.9 \%$ \\
& Enterprise staff & 74 & $17.1 \%$ \\
& Individual management & 15 & $3.5 \%$ \\
& Student & 9 & $2.1 \%$ \\
Education & Retire & 115 & $26.6 \%$ \\
& Unemployed or others & 177 & $40.9 \%$ \\
\hline \multirow{2}{*}{ Economic } & High school and below & 87 & $20.1 \%$ \\
level & College degree & 101 & $23.3 \%$ \\
& Bachelor degree & 156 & $36.0 \%$ \\
\hline \multirow{2}{*}{ Agricultural } & Graduate or above & 89 & $20.6 \%$ \\
products & Below average & 231 & $53.3 \%$ \\
usually & Middle level & 181 & $41.8 \%$ \\
purchased & Above average & 21 & $4.8 \%$ \\
\hline & Fruit & 112 & $25.9 \%$ \\
& Vegetable & 125 & $28.9 \%$ \\
& Meat and egg & 93 & $21.5 \%$ \\
& Aquatic product & 69 & $15.9 \%$ \\
& Other & 34 & $7.8 \%$ \\
\hline
\end{tabular}

\subsection{Reliability and validity}

Following the two-step approach recommended by Anderson and Gerbing, we first examined the measurement model to verify the reliability and validity of the instrument and then assessed the structural model.

AMOS (version 24.0) was used to estimate both the measurement and structural models. As the normality of samples is an important assumption for covariance-based AMOS estimation, we first examined the skewness and kurtosis of the data to assess the normality of samples. The skewness values for the sample ranged from -0.916 to -0.214 which were within the threshold of 3.0 for acceptable skewness. The kurtosis values of items for the two samples were between -0.863 and 1.33 , which were also below Kline's standard of 8 . These two samples were therefore accepted as fulfilling the assumption of normality.

We performed both principal components factor analysis and confirmatory factor analysis (CFA) to assess the reliability and validity of the scales. The Kaiser-Meyer-Olkin (KMO) statistics for the sample was 0.745 , indicating that the data was amenable for factor analysis. All indicators loaded on the expected factors and were higher than 0.6 , while loadings on other factors for all indicators were lower than 0.4 , suggesting good convergent and discriminant validity.

A 5-factor measurement model was set up to further assess construct reliability and validity according to the CFA approach. As shown in [Table 3], the Cronbach's a and Composite Reliability (CR) value of each construct ranged from 0.857 to 0.984 , which were above the suggested threshold of 0.7 . For construct validity, both convergent validity and discriminant validity were examined. Convergent validity was confirmed by examining both the Average 
Variance Extracted (AVE) and indicator loadings. As shown in Table 4, all AVE values were higher than the recommended level of 0.5. The standard loadings of all items were above the desired threshold of 0.7 and significant at 0.001 . This showed good convergent validity.

The discriminant validity is supported when the square root of the AVE for each construct is greater than the correlations between that construct and other constructs. As shown in Table 4, the square roots of the AVEs for both datasets were all greater than the inter-construct correlations depicted in the off-diagonal entries, thus demonstrating discriminant validity.

As the data collected was self-reported from a single source, we tested the data for common method bias using Harman's single factor test. Five factors were extracted from the data. The factors extracted from the sample explained $85.9 \%$ variance, in the collected data. However, the most significant factors for these samples accounted for 39\% (less than $40 \%$ ). The results showed that no single factor dominated the total variance, indicating a lack of common method bias.

Table 3. Results of confirmatory factor analysis

\begin{tabular}{|c|c|c|c|c|c|}
\hline Construct & Indicator & Standard loading ${ }^{1}$ & AVE & $\mathrm{CR}$ & Cronbach's $\alpha$ \\
\hline $\begin{array}{l}\text { Service process } \\
\text { quality }\end{array}$ & $\begin{array}{l}\text { SPQ1 } \\
\text { SPQ } 2 \\
\text { SPQ } 3 \\
\text { SPQ } 4 \\
\text { SPQ } 5 \\
\text { SPQ } 6\end{array}$ & $\begin{array}{l}0.936 \\
0.953 \\
0.955 \\
0.948 \\
0.957 \\
0.954\end{array}$ & 0.904 & 0.983 & 0.982 \\
\hline Service result quality & $\begin{array}{l}\text { SRQ } 1 \\
\text { SRQ } 2 \\
\text { SRQ } 3 \\
\text { SRQ } 4 \\
\text { SRQ } 5 \\
\text { SRQ } 6\end{array}$ & $\begin{array}{l}0.950 \\
0.959 \\
0.958 \\
0.954 \\
0.955 \\
0.956\end{array}$ & 0.913 & 0.984 & 0.984 \\
\hline $\begin{array}{c}\text { Service recovery } \\
\text { quality }\end{array}$ & $\begin{array}{l}\text { SRC } 1 \\
\text { SRC } 2 \\
\text { SRC } 3 \\
\text { SRC 4 }\end{array}$ & $\begin{array}{l}0.965 \\
0.968 \\
0.965 \\
0.965 \\
\end{array}$ & 0.933 & 0.982 & 0.982 \\
\hline $\begin{array}{c}\text { Customer } \\
\text { engagement }\end{array}$ & $\begin{array}{l}\text { CE1 } \\
\text { CE2 } \\
\text { CE3 } \\
\end{array}$ & $\begin{array}{l}0.816 \\
0.824 \\
0.809 \\
\end{array}$ & 0.666 & 0.857 & 0.857 \\
\hline Customer loyalty & $\begin{array}{l}\text { CL1 } \\
\text { CL2 } \\
\text { CL3 } \\
\text { CL4 } \\
\text { CL5 } \\
\text { CL6 }\end{array}$ & $\begin{array}{l}0.796 \\
0.796 \\
0.801 \\
0.794 \\
0.818 \\
0.803\end{array}$ & 0.642 & 0.915 & 0.915 \\
\hline
\end{tabular}

Table 4. Correlations and the square root of AVE (diagonal)

\begin{tabular}{|c|c|c|c|c|c|}
\hline & SPQ & SRQ & SRC & CE & CL \\
\hline SPQ & $\mathbf{0 . 9 5 1}$ & & & & \\
\hline SRQ & 0.513 & $\mathbf{0 . 9 5 6}$ & & & \\
\hline SRC & 0.410 & 0.459 & $\mathbf{0 . 9 6 6}$ & & \\
\hline CE & 0.561 & 0.564 & 0.677 & $\mathbf{0 . 8 1 6}$ & \\
\hline CL & 0.566 & 0.579 & 0.677 & 0.630 & $\mathbf{0 . 8 0 1}$ \\
\hline
\end{tabular}

*Note: SPQ: Service process quality; SRQ: Service result quality; SRC: Service recovery quality; CE: Customer engagement; CL: Customer loyalty. 
After examining the measurement validity and reliability, we tested the proposed hypotheses using AMOS 24.0. After modifying the original model, the actual and recommended values of the model fit indices are listed in [Table 5]. The fit indices of the model were better than the recommended thresholds, demonstrating a good fit between the model and data.

Table 5. Measures of the model fit

\begin{tabular}{|c|c|c|c|c|c|c|}
\hline Fit index & $\mathrm{X}^{2} / \mathrm{df}$ & RMSEA & GFI & CFI & NFI & TLI \\
\hline Recommended range & $<3.84^{\mathrm{a}}$ & $<0.08^{\mathrm{b}}$ & $>0.90^{\mathrm{a}}$ & $>0.90^{\mathrm{a}}$ & $>0.90^{\mathrm{a}}$ & $>0.90^{\mathrm{a}}$ \\
\hline Model value & 1.440 & 0.039 & 0.932 & 0.992 & 0.975 & 0.991 \\
\hline
\end{tabular}

*Note: 1. RMSEA, root mean square error of approximation; GFI, the goodness of fit index; CFI, comparative fit index; NFI, normed fit index; TLI, non-normed fit index. 2. ${ }^{a}$ According to Bentler and Bonett and Lee et al., ${ }^{b}$ According to Browne and Cudeck and Lee et al.

\subsection{Hypotheses testing}

Path modeling was performed to test $\mathrm{H} 1$ to H3. Our results show that the electronic service quality (process quality, outcome quality, recovery quality) has a prominent positive effect on customer engagement and so does the engagement to loyalty. Service recovery quality can not only directly affect customer loyalty, but also indirectly affect customer loyalty through customer engagement, while service process quality and service result quality affect customer loyalty through customer engagement. The results are reported in [Table 6].

Table 6. Structural model results

\begin{tabular}{|c|c|c|c|c|c|c|}
\hline Hypotheses & Structural Path & Estimate & S.E. & T value & $\mathrm{p}$ & Results \\
\hline $\mathrm{H} 1 \mathrm{a}$ & $\mathrm{SPQ} \rightarrow \mathrm{CE}$ & 0.095 & 0.022 & 4.227 & $* * *$ & accepted \\
\hline $\mathrm{H} 1 \mathrm{~b}$ & $\mathrm{SRQ} \rightarrow \mathrm{CE}$ & 0.084 & 0.022 & 3.866 & $* * *$ & accepted \\
\hline $\mathrm{H} 1 \mathrm{c}$ & $\mathrm{SRC} \rightarrow \mathrm{CE}$ & 0.158 & 0.021 & 7.466 & $* * *$ & accepted \\
\hline $\mathrm{H} 2$ & $\mathrm{CE} \rightarrow \mathrm{CL}$ & 0.828 & 0.056 & 14.752 & $* * *$ & accepted \\
\hline $\mathrm{H} 3 \mathrm{a}$ & $\mathrm{SPQ} \rightarrow \mathrm{CL}$ & 0.013 & 0.015 & 0.903 & 0.367 & rejected \\
\hline $\mathrm{H} 3 \mathrm{~b}$ & $\mathrm{SRQ} \rightarrow \mathrm{CL}$ & 0.019 & 0.014 & 1.304 & 0.192 & rejected \\
\hline $\mathrm{H} 3 \mathrm{c}$ & $\mathrm{SRC} \rightarrow \mathrm{CL}$ & 0.031 & 0.015 & 2.104 & $0.035^{*}$ & accepted \\
\hline
\end{tabular}

Note: 1. Note: Note: SPQ: Service process quality; SRQ: Service result quality; SRC: Service recovery quality; CE: Customer engagement; $C L$ : Customer loyalty. $2 .{ }^{*} p<0.05, * * p<0.01, * * * p<0.001$

\section{Discussion and conclusions}

\subsection{General discussion}

From the perspective of consumers of an e-commerce platform for agricultural products, this paper brings customer engagement into the research framework of the online purchase of agricultural products and discusses the impact of service quality of e-commerce platform for agricultural products on customer loyalty and the mediating role of customer engagement in this process. The results show that the service quality of different dimensions has an impact on customer engagement; the service recovery quality of E-Business platform of agricultural can not only directly promote customer loyalty, but also indirectly affect customer loyalty through customer engagement; Service process quality and service result quality only affect customer loyalty through customer engagement. 


\subsection{Management implications}

This paper takes the e-commerce platform of agricultural products as the research object, verifies the strengthening effect of service quality on customer loyalty, and predicts customer loyalty through the fit between service quality and customer. The research results provide ideas and theoretical guidance for the development of customer loyalty on the e-commerce platform of agricultural products, and also lay a foundation for the further maintenance of loyal customers, which has certain guiding significance.

First of all, the competition of more and more e-commerce platforms for agricultural products is increasingly fierce. When consumers purchase agricultural products on the ecommerce platform, the service process quality of the platform is the first perceived service quality of consumers, and it is also the pre-factor of customer engagement and loyalty. An Ecommerce platform should adjust its strategy according to its characteristics and market changes. Strengthen the function of the e-commerce platform of agricultural products, provide real and effective information of agricultural products for consumers, reduce the process of online purchase of agricultural products, and ensure the safety of online payment, so that consumers have a good experience in the process of online shopping.

Secondly, this study also confirms the importance of the quality-of-service results. Agricultural products e-commerce platform should not only improve the service quality of online shopping but also pay attention to the timely and high-quality delivery of agricultural products to consumers. High-quality service quality is the main source of customer engagement and customer loyalty. Therefore, the e-commerce platform should control packaging, delivery time, and logistics standards more strictly according to the characteristics of agricultural products.

Thirdly, it is precisely because of the particularity of agricultural products themselves that there is a great difference between buying ordinary goods (clothes, books, etc.) online. Therefore, when the service of an e-commerce platform appears, the service remedy measures of ordinary commodities in the e-commerce environment cannot be applied to the e-commerce platform environment of agricultural products. The e-commerce platform should be aware that when there is a lack of service, it should pay attention to active two-way communication with customers, quickly solve complaints, pay compensation as promised, timely understand customers' satisfaction with the remedial quality, and promote customers' trust again. In the process of interactive experience exchange, the agricultural products e-commerce platform should cultivate and retain continuous interaction with consumers, to form a fit and achieve customer loyalty.

Finally, enterprises and customers should create value together. We should implement customer engagement management for customers, and customer engagement can solve this problem well. In the process of creating value with enterprises, congenial customers invest in cognition, emotion, and behavior, which not only create value for enterprises but also create value for themselves. The process of creating value together is the process of continuous contact between enterprises and corresponding customers, and customer loyalty will be formed in the process of experiencing service. Therefore, the goal of the e-commerce platform for agricultural products should transit from cultivating customer satisfaction to creating suitable customers and co-creating value activities. The formation of fit customers can not only maintain and promote corporate profits but also maintain their loyalty to the platform and become loyal customers. 


\subsection{Limitations and future research}

This paper analyzes the different dimensions of service quality of agricultural products ecommerce platforms and the influence path of customer loyalty through customer engagement. Although the research of this paper extends the research of customer loyalty of agricultural products e-commerce platform to a certain extent, there are still the following deficiencies, and as the direction of further research.

First of all, the e-commerce platform of agricultural products mentioned by the interviewees in this paper covers many e-commerce platforms such as Taobao, Jingdong, Shunfeng, etc., but it is mainly the e-commerce platform with high popularity. The promotion of this conclusion is necessary to be further verified in other e-commerce platforms of agricultural products.

Secondly, this study collects data for the platforms that consumers often buy. Although the research model and hypothesis have been well verified, the research does not classify the types of agricultural products e-commerce platforms. Whether the research conclusions of this paper apply to other types of agricultural products e-commerce platforms also needs further verification.

Finally, in future research, we can consider some potentially relevant regulatory variables, such as the personal characteristics of consumers, the type of agricultural products purchased, etc. (in this paper, the respondents mainly buy fresh products) into the scope of the study, and improve the model, to get more accurate and systematic conclusions.

\section{Acknowledgment}

This work was supported by the grant of no. X20006S from the doctoral fund of Shandong Jianzhu University, China.

\section{References}

[1] T. Hu and T. Fu, "Analysis of e-commerce development of agricultural products in China," Agricultural economic issues, vol.26. no.5, pp.23-27, (2005)

[2] D. Wang, "Research on the consumption of national culture - focusing on "Enshi Tujia daughter association," Journal of Chongqing Three Gorges University, vol.28, no.6, pp.87-90, (2012)

[3] Y. Li and G. F. Wang, "Thoughts and suggestions on the development of fresh organic e-commerce in China," China management Information, no.14, pp.85-86, (2013)

[4] D. Seto-Pamies, "Customer loyalty to service providers: Examining the role of service quality, customer satisfaction, and trust,” Total Quality Management \& Business Excellence, vol.23, no.11-12, pp.1257-1271, (2012)

[5] H. Dai, T. Hu, and X. H. Zhang, "Continued use of mobile technology-mediated services: A value perspective," Journal of Computer Information Systems, vol.54, no.2, pp99-109, (2014)

[6] C. W. Yoo, G. L. Sanders, and J. Moon, "Exploring the effect of e-WOM participation on e-loyalty in ecommerce," Decision Support Systems, vol.55, no.3, pp.669-678 (2013)

[7] T. Levitt, "Production-line approach to service," Harvard Business Review

[8] W. E. Sasser, R. P. Olsen, and D. D. Wyckoff, "Management of service operations: Text, cases, and readings," Boston: Allyn and Bacon

[9] C. A. Gronroos, "Service quality model and its' marketing implication," European Journal of Marketing, vol.18, no.4, pp.36-44

[10] A. Parasuraman, V. A. Zeithaml, and L. A. Berry, "Conceptual model of service quality and its implications for future research," Journal of Marketing, vol.49, no.3, pp.41-50

[11] J. S. Lei, "Review of service and service quality theory," Productivity research, vol.20, pp.425-430, (2007) 
[12] V. A. Zeithaml, A. Parasuraman, and Malhotra, "E-service quality: Definition, dimensions and conceptual model," Journal of Service Research, vol.7, no.3, pp.213-233, (2000)

[13] J. Gummerus, V. Liljander, and M. Pura, "Customer loyalty to content-based websites: The case of an online health-care service," Journal of Services Marketing, vol.8, no.3, pp.175-186, (2004)

[14] S. W. Chen, "Significance and countermeasures for developing e-commerce of agricultural products," Agricultural Economy, no.3, pp.128-129, (2016)

[15] C. Q. Li, Y. Sun, and Y. L. Guo, "Research on determinants and measurement model of e-service quality," Operations Research and Management, no.3, pp.135-139, (2004)

[16] H. H. Bauer, T. Falk, and M. Hammerschmidt, "E-trans-qual: A transaction process-based approach for capturing service quality in online shopping," Journal of Business Research, vol.59, no.7, pp.866-875, (2006)

[17] C. Thirumal Azhagan, S. Gangadharan, U. Madhanrajan, "Computational analysis for service quality determinants in retail sectors using SERVQUAL model," Materials Today: Proceedings, vol.21, no.1, pp.2747, (2021)

[18] R. Thakur, "Customer engagement and online reviews," Journal of Retailing and Consumer Services, no.41, pp.48-59, (2018)

[19] T. Bijmolt, P. Leeflang, and F. Block, "Analytics for customer engagement," Journal of Service Research, vol.13, no.3, pp.341-356, (2010)

[20] S. L. Vargo and R. F. Lusch, “Consumers' evaluative reference scales and social judgment theory,” Emerald Group Publishing Limited, (2004)

[21] C. Gronroos, "Service logic revisited: Who creates value? And who co-creates?" European. Business Review, vol.20. no.4, pp.298-314, (2008)

[22] V. Kumar, J. A. Petersen, and R. P. Leone, "Driving profitability by encouraging customer referrals: Who, when, and how," Journal of Marketing, vol.74, no.5, pp1-17, (2010)

[23] C. Oh, Y. Roumani, J. Nwankpa, and H. Hu, "Beyond likes and tweets Consumer engagement behavior and movie box office in social media," Inf. Manag, vol.54, no.1, pp.25-37, (2017)

[24] E. Karahanna, S. Xu, Y. Xu, and N. Zhang, "The needs-affordances-features perspective for the use of social media," MIS Q, vol.42, no.3, pp.737-756, (2018)

[25] V. Shankar, A. K. Smith, and A. Rangaswamy, "Customer satisfaction and loyalty in online and offline environments," International Journal of Research in Marketing, vol.20, no.2, pp.153-175, (2003)

[26] S. D. Vivek, S. E. Beatty, and R. M. Morgan, "Consumer engagement: Exploring customer relationships beyond purchase," Journal of Marketing Theory and Practice, vol.20, no.2, pp.127-145, (2012)

[27] K. So, C. King, and B. A. Sparks, "The role of customer engagement in building consumer loyalty to tourism brands," Journal of Travel Research, vol.55, no.1, pp.64-78, (2014)

[28] R. J. Brodie, L. D. Hollebeek, and B. Juric, "Customer engagement conceptual domain, fundamental propositions, and implications for research," Journal of Service Research, vol.14, no.3, pp.252-271, (2011)

[29] J. Van Doorn, K. N. Lemon, and V. Mittal, "Evaporation source with electron-bombardment heating for various applications: Renner,” Journal of Service Research, vol.13, no.3, pp253-266, (2010)

[30] A. Haghkhah, S. M. Rasoolimanesh, and A. A. Asgari, "Effects of customer value and service quality on customer loyalty: Mediation role of trust and commitment in business-to-business context," Management Research and Practice, pp.12, (2020)

[31] E. W. Anderson and M. W. Sullivan, The antecedents and consequences of customer satisfaction for firms," Marketing Science, vol.12, no.2, pp.125-143

[32] D. Gremler and D. Wayne, "The effects of satisfaction, switching costs, and interpersonal bonds on service loyalty," doctoral dissertation, Arizona State University, pp.43-48

[33] J. L. Han and F. X. Wei, "Research on the interactive relationship between customer satisfaction and customer loyalty," Nankai Management Review, vol.4, pp.8-10, (2001)

[34] J. Lu and S. L. Ge, "On the core of enterprise customer relationship management loyalty," Journal of Huazhong Agricultural University (social science edition), no.2, pp.57-60, (2002) 
[35] V. Shankar, A. K. Smith, and A. Rangaswamy, "Customer satisfaction and loyalty in online and offline environments," International Journal of Research in Marketing, vol.20, no.2, pp.153-175, (2003)

[36] A. S. Dick and K. Basu, "Customer loyalty: Toward an integrated conceptual framework," Journal of the Academy of Marketing Science, vol.22, no.2, pp.99-113

[37] R. L. Oliver, "Satisfaction: A behavioral perspective on the consumer," Asia Pacific Journal of Management, vol.2, no.2, pp.285-286

[38] Q. X. Ma and P. W. Zhang, “Analysis of factors influencing customer loyalty,” Regional Economic Review, no.4, pp.34-35, (2003)

[39] J. Lu, "Research on the driving factors of service loyalty: Review and conception," Economic Science, no.3, pp.108-119, (2005)

[40] R. Kuvykaite and Z. Piligrimiene, "Consumer engagement into brand equity creation," Procedia-Social and Behavioral Sciences, vol.156, no.11, pp.479 483, (2014)

[41] M. Hülsmann, A. Schwientek, and B. Korsmeier, "Creating customer value in logistics: Contributions and limitations of autonomous cooperation-based technologies," Springer Berlin Heidelberg, (2011)

[42] T. H. A. Bijmolt, P. S. H. Leeflang, and F. Block, "Analytics customer engagement," Journal of Service Research, vol.13, no.3, pp341-356, (2010)

[43] A. R. Reitz, “Online consumer engagement: Understanding the antecedents and outcomes,” Ph. D. Dissertation, Colorado State University, (2012)

[44] J. Claussen, T. Kretschmer, and P. Mayrhofer, "The effects of rewarding user engagement: The case of facebook apps," Information Systems Research, vol.24, no.1, pp.186-200, (2013)

[45] R. J. Brodie, L. D. Hollebeek, and B. Juric, "Customer engagement conceptual domain, fundamental propositions, and implications for research," Journal of Service Research, vol.14, no.3, pp.252-271, (2011)

[46] C. X. Wang and J. Wen, "Service quality, consumption value, passenger satisfaction, and behavior intention," Nankai management review, no.6, pp.11-15, (2001)

[47] N. Samala, S. Singh, R. Nukhu, and M. Khetarpal, "Investigating the role of participation and customerengagement with tourism brands (CETB) on social media," Academy of Marketing Studies Journal, no.23, pp.1-16, (2019)

[48] H. E. Celik and V. Yilmaz, "Extending the technology acceptance model for adoption of e-shopping by consumers in Turkey," Journal of Electronic Commerce Research, vol.12, no.2, pp.152-164, (2011)

[49] C. Cheung, G. Chan, and M. Limayem, "A critical review of online consumer behavior: Empirical Research," Journal of Electronic Commerce in Organizations, vol.3, no.3, pp.1-19, (2012)

[50] M. L. Zhang, L. Y. Guo, M. Hu, and W. H. Liu, "Influence of customer engagement with company social networks on stickiness: Mediating effect of customer value creation," International Journal of Information Management, vol.37, no.3, pp.229-240, (2017) 